\title{
FERDINAND DE SAUSSURE: Strukturalisme dan Sumbangsihnya Bagi Dunia Penafsiran Alkitab
}

\section{Yudi Jatmiko*}

\begin{abstract}
Despites the rampant approach of post-structuralism hermeneutics which disregards structural pattern and sign systems, structuralism plays a vital role in the heart of modern hermeneutics. As a reading tool toward signs (and inter-texts) in society, structuralism has laid a solid foundation for philologist to decipher meaningful message that is delivered through sign. In the world of bible hermeneutics, structuralism contributes significantly to the diversity and richness of textual interpretation to Scripture. This research endeavors to expound structuralism as a tool of modern hermeneutics and show its contribution to the world of bible interpretation. Taking Luke 18:1-8 and Psalms 8:1-9 as teaching tools, the writer discusses the ability as well as the limitation of structuralism in understanding the texts.
\end{abstract}

Keywords: Ferdinand de Saussure, Structuralism, Signified-Signifier, Sign, Langue-Parole, Sintagmatic-Paradigmatic, Synchronic-Diachronic

Abstrak: Terlepas dari maraknya pendekatan hermeneutika pascastrukturalisme yang mengabaikan tatanan struktur dan sistem tanda, strukturalisme memainkan peranan yang vital dalam jantung hermeneutika modern. Sebagai sebuah alat baca terhadap tanda (dan keterjalinan teks) dalam masyarakat, strukturalisme memberikan fondasi yang kokoh bagi peneliti bahasa dan teks untuk mengkaji pesan bermakna yang disampaikan melalui tanda. Dalam dunia hermeneutika Alkitab, strukturalisme memberikan kontribusi yang signifikan bagi keragaman dan kekayaan penafsiran teks-teks Kitab Suci. Penelitian ini berusaha untuk memaparkan strukturalisme sebagai sebuah perangkat

* Penulis adalah rohaniwan Gereja Presbyterian Bukit Batok, Singapura. Penulis dapat dihubungi melalui email: yudi3036@yahoo.com. 
hermeneutika modern dan menunjukkan sumbangsih strukturalisme bagi dunia penafsiran Alkitab. Menggunakan teks Lukas 18:1-8 dan Mazmur 8:1-9 sebagai alat peraga, penulis mendiskusikan kemampuan dan keterbatasan pendekatan strukturalisme dalam mengkaji teks.

Kata Kunci: Ferdinand de Saussure, Strukturalisme, Signified-Signifier, Tanda, Langue-Parole, Sintagmatik-Paradigmatik, Sinkronik-Diakronik.

\section{Pendahuluan}

Ferdinand Mongin de Saussure, melalui karya monumentalnya, Course in General Linguistic, dapat dikatakan sebagai peletak dasar seluruh pemikiran strukturalisme. ${ }^{1}$ Melalui strukturalisme sebagai sebuah sistem atau perangkat hermeneutika modern, Saussure memengaruhi bukan hanya ranah bahasa, tetapi juga antropologi, sejarah, kritik sastra, bahkan hermeneutika Alkitab. Dalam dunia hermeneutika Alkitab, strukturalisme memberikan sumbangsih yang signifikan bagi keragaman dan kekayaan penafsiran teks-teks Kitab Suci.

Tulisan ini berusaha memaparkan: pertama, strukturalisme sebagai sebuah perangkat hermeneutika modern; kedua, sumbangsih strukturalisme bagi dunia penafsiran Alkitab. Fokus pembahasan strukturalisme dan sumbangsihnya bagi dunia penafsiran Alkitab dipilih dengan mempertimbangkan dua hal: pertama, strukturalisme merupakan sebuah pendekatan linguistik yang berdampak luas bagi dunia, bukan hanya dalam ranah bahasa, tetapi juga dalam disiplin-disiplin ilmu lainnya; kedua, pendekatan strukturalisme erat kaitannya dengan studi genre

1. Encyclopedia Americana Vol. 24 (Danbury: Grolier, 1994), 309. 
dalam hermeneutika modern. Penulis meyakini, terlepas dari situasi pascamodernisme dan pascastrukturalisme dewasa ini, pendekatan strukturalisme tetap memiliki sumbangsih yang konstruktif bagi dunia hermeneutika modern, khususnya penafsiran Alkitab.

\section{Strukturalisme Sebagai Sebuah Perangkat Hermeneutika Modern}

Terminologi "strukturalisme" tidak dapat dilepaskan dari tokoh genius yang menggagas teori ini: Ferdinand Mongin de Saussure (18571913). ${ }^{2}$ Saussure adalah seorang ahli bahasa dari Swiss yang sangat berbakat. la dilahirkan di Geneva, 26 November 1857. Dalam usia dini Saussure diperkenalkan dengan studi bahasa. Menikmati studi tersebut, Saussure memperdalamnya dengan mempelajari berbagai bahasa di Universitas Geneva, antara lain: Sansekerta, Yunani, Latin, Inggris, Perancis, dan Jerman. Pada tahun 1876, ia melanjutkan studi magister di Univerity Leipzig. Dua tahun kemudian, pada usia 21, Saussure mendapat kesempatan untuk melanjutkan studinya di Berlin selama satu tahun. Di sini ia menulis satu-satunya karya lengkapnya yang berjudul Dissertation on the Primitive Vowel System in Indo-European Languages. Karya ini menghantarkannya pada gelar doktor di Leipzig. Tidak lama kemudian

2. Penting untuk dipahami bahwa konsepsi strukturalisme bukanlah milik Saussure semata. Ada tokoh-tokoh lain yang turut mengembangkan pendekatan ini dan menjadikannya relevan dalam tiap bidang ilmu yang diminati oleh tokoh yang bersangkutan. Beberapa di antara tokoh-tokoh tersebut adalah sebagai berikut: Vladimir Propp (sastra), Claude Levi-Strauss dan Roman Jakobson (antropologi), Jacques Lacan (psikoanalisis), Jean Piaget (psikologi), Michel Foucault (sejarah), Thomas Kuhn (sains), Louis Althusser (analisis sosial), dan Roland Barthes (semiotika). Tokoh Ferdinand Saussure dipilih dalam tulisan ini karena dialah yang meletakkan dasar dari pendekatan ini. 
Saussure mengajar di Paris. Saussure menghabiskan waktu 11 tahun mengajar bahasa-bahasa kuno dan modern sebelum akhirnya kembali ke Geneva pada tahun 1891. Di Universitas Geneva Saussure mengajar bahasa Sansekerta dan Indo-Eropa sampai akhir hidupnya. Karya Saussure yang paling berpengaruh dalam dunia hermeneutika adalah Course in General Linguistics (Cours de linguistique générale).

Course in General Linguistics merupakan karya Saussure yang diterbitkan setelah kematiannya. Ini merupakan sebuah kumpulan catatan kuliah Charles Bally dan Albert Sechehaye ketika mengikuti kuliah-kuliah Saussure di Paris. Di dalam karya ini Saussure banyak menuangkan pemikiran-pemikiran yang kreatif. Pemikiran-pemikiran inilah yang menjadi bibit dari pendekatan yang kemudian dikenal orang secara luas dengan istilah "strukturalisme".

\section{Strukturalisme}

'Secara umum, strukturalisme dapat dipahami sebagai "a blueprint for describing how the structures of our social and cultural life are constituted, and the way in which once constituted they function as a system of signs." 3 Para penganut strukturalisme percaya bahwa tiap objek penelitian memiliki struktur untuk diteliti. Allison Assiter menggarisbawahi hal ini ketika menyatakan bahwa

There are four common ideas regarding structuralism that form an 'intellectual trend'. Firstly, the structure is what determines the position of each element of a whole. Secondly, structuralists

3. Carol Sanders, "Introduction: Saussure today," dalam The Cambridge Companion to Saussure, C. Sanders, ed. (Cambridge: Cambridge University, 2004), 2. 
believe that every system has a structure. Thirdly, structuralists are interested in 'structural' laws that deal with coexistence rather than changes. And finally structures are the 'real things' that lie beneath the surface or the appearance of meaning. ${ }^{4}$

Sebagaimana berlaku atas tiap objek penelitian, demikian juga halnya dengan teks.

Dalam konsepsi strukturalisme, teks sebagai sebuah objek penelitian memiliki struktur yang saling terkait dan mengusung makna yang hendak disampaikan oleh penulis. ${ }^{5}$ Struktur teks menjadi satusatunya sumber bagi proses pemaknaan. Yang dimaksud dengan struktur teks di sini adalah unsur-unsur di dalam teks yang saling terkait dan membentuk makna teks. Unsur-unsur tersebut dapat merupakan tata bahasa (dalam sebuah kalimat), keteraturan dan ketidakteraturan bunyi (secara khusus dalam puisi), serta unsur-unsur bawaan dalam sebuah narasi (peristiwa, penokohan, tempat, alur, dan sebagainya yang muncul dalam sebuah teks narasi).

Selain menjadi sumber, struktur teks juga menjadi batasan penelitian. Dalam konsepsi strukturalisme, fokus penelitian terletak hanya pada teks. Dalam hal ini pengarang dan pembaca tidak memiliki ruang dalam pemaknaan teks. Sebuah teks diperlakukan sebagaimana adanya teks itu tanpa melihat sisi kepengarangan (latar belakang sejarah, budaya, konsepsi pemikiran, dan sebagainya) dan sisi pembaca (latar belakang

4. “Althusser and structuralism," The British Journal of Sociology 35 (1984), 272-96.

5. Thomas Kazen, "Level of Explanation for Ideas of Impurity: Why Structuralist and Symbolic Models Often Fail while Evolutionary and Cognitive Models Succeed," Journal of Ancient Judaism 9, no. 1 (January 2018): 75-100. 
pembaca, budaya pada saat teks itu dibaca, sudut pandang pembaca dan sebagainya). Dengan demikian, teks menjadi bersifat otonom dan ada pada dirinya sendiri. ${ }^{6}$ Selain struktur, konsep langue dan parole juga merupakan hal yang sangat penting dalam strukturalisme.

\section{Langue dan Parole}

Dalam strukturalisme, langue (language) dipahami sebagai "the social, impersonal phenomenon of language as a system of signs" sedangkan parole (speech) sebagai "the individual, personal phenomenon of language as a series of speech acts made by a linguistic subject." 8 Parole merupakan tindakan ujaran yang dilakukan oleh tiap pengguna bahasa, bersifat pribadi, dan tentunya berbeda perwujudannya dari satu pengujar ke pengujar yang lainnya. Langue adalah sistem yang mengikat dari tiap ujaran yang berbeda tersebut. Sebagai contoh, ada tiga pengujar: A, B, dan C.

Pengujar A berkata, "Saya sedang mengetik tugas laporan penelitian." Pengujar B berkata, "Kami mendengarkan firman Tuhan"

Pengujar C berkata, "Pak dosen memberi kami tugas untuk memperkaya pemahaman kami tentang sumbangsih hermeneutika modern bagi dunia penafsiran Alkitab."

6. William W. Klein, et al., Introduction to Biblical Interpretation (Nashville: Thomas Nelson, 2004), 65.

7. Ferdinand de Saussure, Course in General Linguistics (Chicago: Open Court, 1986), 9-10; Grant R. Osborne, The Hermeneutical Spiral (Downers Grove: IVP, 2006), 472; Anthony C. Thistleton, New Horizon in Hermeneutics (Grand Rapids: Zondervan, 1992), 47.

8. Saussure, Course in General Linguistics, 9-10. 
Pengamatan sekilas akan memunculkan kesimpulan bahwa tiap pengujar memiliki kalimat yang berbeda. Inilah parole. Pengamatan yang lebih jauh akan memperjelas bahwa tiap ujaran (parole) yang berbeda itu memiliki sebuah struktur/sistem bahasa yang sama, yaitu "subjek dan predikat". Kata "saya", "kami", dan "pak dosen" merupakan subjek dalam tiap parole tersebut, sedangkan kata "mengetik", "mendengarkan", dan "memberi" merupakan predikat dari ketiga subjek yang telah disebutkan tadi. Dengan demikian, ketiga parole tadi membentuk sebuah sistem bahwa sebuah kalimat harus terdiri dari subjek dan predikat. Inilah langue. Kedua hal ini (langue dan parole) membentuk Language atau bahasa sebagai sistem tanda dalam sebuah komunitas pengguna bahasa.

Tanda (Sign)

Dalam konsepsi Saussure, tanda (sign) merupakan sebuah entitas ganda yang terdiri dari "signifier" dan "signified". 9 Saussure menggambarkannya sebagai berikut:

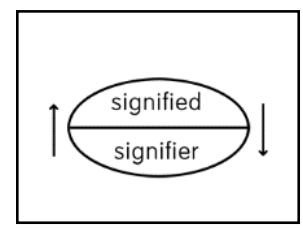

Fig. 1 - The Sign

Signifier adalah "sound image" atau bunyi bahasa, sedangkan signified adalah konsep atau proyeksi mental yang muncul dari bunyi 
tersebut. Misalnya, seorang pengujar mengucapkan ${ }^{10}$ kata "kursi". Konsep atau proyeksi mental yang muncul adalah "sebuah benda untuk diduduki, umumnya memiliki sandaran dengan kaki sebagai penunjang alas duduk." Kata "kursi" yang dilafalkan adalah signifier, sedangkan konsepsi mental yang muncul atas pelafalan tersebut adalah signified. Kedua hal ini (signifier dan signified) membentuk tanda (sign) dalam bahasa. Saussure kemudian menyebut pola ini sebagai semiology atau semiotics, yaitu "the study of signs or symbols." ${ }^{11}$

\section{Sintagmatik dan Paradigmatik}

Hal lain yang juga dibahas dalam strukturalisme adalah hubungan antara sintagmatik dan paradigmatik dalam teks. Sintagmatik merupakan tampilan struktur dari teks yang ada, sedangkan paradigmatik adalah worldview (paradigm) yang muncul sebagai hasil terhadap analisa aspek sintagmatik tersebut. Dalam kaitan kritik sastra, sintagmatik merupakan "struktur permukaan" (surface structure), sedangkan paradigmatik adalah

10. Dalam hal ini, pengujar tersebut melafalkan atau mem-“bunyi”-kan kata "kursi".

11. Jeppe Sinding Jensen, "Semiotics of Religion: Once Lost - and now Found," Religion 44, no.1 (January 2014): 130-35. Dalam perkembangan ilmu hermeneutika modern, strukturalisme, khususnya mengenai aspek studi tanda ini, merupakan embrio bagi semiotika yang secara khusus dikembangkan oleh Roland Barthes. Hal ini nantinya akan memberi ruang bagi teori dekonstruksi yang digagas oleh Jacques Derrida. Derrida melihat adanya kemungkinan ruang antara signifier dan signified. Bagi Derrida, apa yang dirujuk oleh signifier tidak hanya satu buah signified, tapi multiple signified. Dengan demikian, pemaknaan sebuah kata bisa sangat bervariasi tergantung oleh siapa dan dalam konteks apa kata itu digunakan. Hal ini dikenal dengan proses "penundaan makna" atau defer (Osborne, The Hermeneutical, 474; Aryeh Amihay, "Biblical Myths and the Inversion Principle: A Neostructuralist Approach," Journal of Biblical Literature 137, no. 3 [2018]: 555-79). 
"struktur isi" (deep structure). ${ }^{12}$ Para pendukung strukturalisme percaya bahwa meaning dari sebuah teks terdapat dalam deep structure. Dalam konsepsi strukturalisme, tugas setiap penafsir adalah memecahkan kode (decoding) "struktur permukaan" supaya mendapatkan meaning di dalam "struktur isi". Ambil contoh pasangan kata-kata sebagai berikut: cat-cats, bat-bats, rabbit-rabbits, carrot-carrots. Analisis sintagmatik terhadap pasangan kata tersebut adalah kumpulan kata di sebelah kiri menunjukkan bentuk tunggal, sedangkan di sebelah kanan menunjukkan bentuk jamak. Analisis paradigmatik menunjukkan bahwa untuk mendapatkan bentuk jamak dari kumpulan kata benda berakhiran " $\mathrm{t}$ " adalah dengan menambahkan huruf "s" di akhir kata tersebut. Dengan demikian, aspek paradigmatik merupakan "benang merah" yang didapatkan setelah melakukan analisis sintagmatik.

Sinkronik dan Diakronik

Hubungan antara sinkronik dan diakronik merupakan hal penting yang dibahas dalam strukturalisme. Sebagai sebuah pendekatan yang bersifat text-oriented, strukturalisme sangat menentang aspek diakronik, yaitu metode analisis yang mempertimbangkan aspek sejarah dari objek penelitian. Sebaliknya, strukturalisme sangat menekankan aspek sinkronik yang memfokuskan penelitian pada sebuah objek sebagaimana objek itu ada pada saat tertentu tanpa mempertimbangkan sejarahnya. Saussure menggambarkan hubungan kedua aspek ini sebagai berikut:

12. Saussure, Course in General Linguistics, 9-10. 


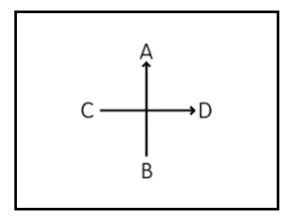

Fig. 2 - The Synchronic and Diachronic Axes

Garis vertikal $A B$ menunjukkan aspek sinkronik, sedangkan garis horizontal CD menunjukkan aspek diakronik. Saussure menegaskan bahwa yang terpenting adalah aspek sinkronik karena dengan memfokuskan penelitian pada aspek sinkronik, makna yang murni akan muncul dan didapat tanpa dipengaruhi oleh unsur-unsur di luar objek tersebut, yang sangat mungkin terjadi jika melakukan pendekatan diakronik. Jika kedua hal ini dihubungkan dengan teks, maka pendekatan sinkronik lebih memperlakukan teks sebagaimana adanya teks tersebut pada saat sedang diteliti. Sebaliknya, pendekatan diakronik akan mempertimbangkan berbagai unsur luar teks seperti: terjemahan lain, teks-teks yang berkaitan dengan teks tersebut, dan sebagainya.

\section{Sumbangsih Strukturalisme Bagi Dunia Penafsiran Alkitab}

Berkaitan dengan studi Alkitab, Bruce Corley, Steve Lemke, dan Grant Lovejoy mendefinisikan strukturalisme sebagai

A study of the structure of the language to which the biblical text conform in order to be intelligible; often concerned primarily with the sentence and smaller units. It has also been called stylistic criticism. In a wider sense, it examines the structural features of biblical narratives that can be analyzed in terms of underlying modes of expression inherent to all human thought. Interest of the 
author's purpose and historical dimensions of the text are minimal. ${ }^{13}$

Hermeneutika modern, secara khusus strukturalisme, memberikan sumbangsih yang luas bagi dunia penafsiran Alkitab. Sumbangsih strukturalisme bagi dunia penafsiran Alkitab mewujud dalam dua hal: pertama, strukturalisme mendorong para penafsir Alkitab untuk berorientasi pada teks, bukan pada pengarang/penulis (author) atau pada pembaca (reader); kedua, strukturalisme menolong penafsir Alkitab untuk memperlakukan teks berdasarkan genre teks tersebut. Fokus yang lebih dalam terhadap teks membawa dunia hermeneutika Alkitab kepada pengkajian yang lebih kaya dan bervariasi karena mempertimbangkan unsur-unsur atau struktur yang membentuk teks: tata bahasa, arti kata, unsur-unsur puisi, elemen-elemen narasi, bahkan keunikan bentuk teks itu sendiri (genre).

Berbanding terbalik dengan sisi positif di atas, strukturalisme juga memiliki kelemaham terkait dunia penafsiran Alkitab. Kelemahan strukturalisme tampak dalam dua hal: pertama, pendekatan strukturalisme bersifat ahistorikal; kedua, strukturalisme mengabaikan pengarang dan sudut pandang teologinya untuk mendapatkan pemaknaan teks. Dengan demikian, strukturalisme memberikan sumbangsih yang signifikan bagi pertumbuhan hermeneutika modern, terlepas dari kelemahan yang ada. ${ }^{14}$

13. Biblical Hermeneutics (Nashville: Broadman \& Holman, 1996), 380.

14. Larry W. Hurtado, "Fashions, Fallacies and Future Prospects in New Testament Studies," Journal of the Study of the New Testament 36, no. 4 (2014): 299329. 
Fokus Kepada Teks

Secara positif, strukturalisme menolong penafsir Alkitab untuk memberikan fokus yang lebih ketat kepada teks sebagai objek penelitian. Ini sangat berguna dalam tahap awal proses eksegesis, khususnya analisis konteks sastra. Gordon D. Fee, seorang ahli dalam hermeneutika Alkitab memberikan rincian penjelasan yang sangat bermanfaat untuk melihat sumbangsih strukturalisme bagi proses penafsiran teks. Bersama dengan Douglas Stuart, Fee menyatakan bahwa "the aim of good interpretation is simple: to get at the "plain meaning of the text."'15 Makna dasar dari teks (the plain meaning of the text) ini tersimpan dalam keterjalinan struktur teks. Menurut Fee dan Stuart, inilah yang dikejar oleh seorang penafsir yang baik. Strukturalisme yang berorientasi kepada struktur teks akan menjadi perangkat hermeneutika yang bermanfaat dalam hal ini. Dengan demikian, pemaknaan dari teks sangat bergantung pada analisis struktur permukaan teks (surface structure). Sebagai contoh, penelitian atas struktur teks terhadap Lukas 18:1-8 akan menghasilkan bentuk sebagai berikut:

Perumpamaan Tentang Hakim Yang Tak Benar (Lukas 18:1-8) Literary Analysis (Analisis Sastra)

\section{A. Struktur Teks}

1 Yesus mengatakan suatu perumpamaan kepada mereka untuk menegaskan, bahwa mereka harus selalu berdoa dengan tidak jemu-jemu.

15. Gordon D. Fee dan Douglas Stuart, How to Read the Bible for All Its Worth (Grand Rapids: Zondervan, 2003), 18. 
2 Kata-Nya:

"Dalam sebuah kota

ada seorang hakim

yang tidak takut akan Allah

dan tidak menghormati seorangpun.

3 Dan di kota itu

ada seorang janda

yang selalu datang kepada hakim itu

dan berkata: Belalah hakku terhadap lawanku.

4 Beberapa waktu lamanya hakim itu menolak.

Tetapi kemudian ia berkata dalam hatinya:

Walaupun aku tidak takut akan Allah

dan tidak menghormati seorangpun,

5 namun karena janda ini menyusahkan aku,

baiklah aku membenarkan dia,

supaya jangan terus saja ia datang

dan akhirnya menyerang aku."

6 Kata Tuhan:

"Camkanlah apa yang dikatakan hakim yang lalim itu!

7Tidakkah Allah

akan membenarkan orang-orang pilihan-Nya

yang siang malam berseru kepada-Nya?

Dan adakah la

mengulur-ulur waktu sebelum menolong mereka?

8 Aku berkata kepadamu:

la akan segera membenarkan mereka.

Akan tetapi,

jika Anak Manusia itu datang, adakah la mendapati iman di bumi?"

Dalam analisis struktur teks di atas, penafsir akan melihat pola-pola kalimat yang berulang mengikuti sistem (langue) yang berlaku dalam tata bahasa Indonesia. Subjek sebuah kalimat disejajarkan dengan subjeksubjek dalam kalimat yang lain. Begitu juga dengan predikat, objek, dan kata keterangan. Melalui penyejajaran bentuk ini, penafsir diharapkan 
mampu melihat alur pikir penulis dengan lebih jelas. Alur pikir ini tercermin dalam bentuk baru dari teks sehingga makna teks dapat ditemukan dengan lebih mudah.

Selain untuk rekonstruksi ulang struktur teks, pendekatan strukturalisme juga menolong penafsir dalam menentukan batasan teks, kesatuan teks, dan pembagian struktur teks. ${ }^{16}$ Proses ini erat kaitannya dengan aspek sintagmatik dalam strukturalisme. Analisis strukturalisme lebih jauh terhadap teks di atas akan menghasilkan bentuk sebagai berikut:

B. Batasan Teks

- Permulaan dari teks ini dimulai dengan tujuan dari perumpamaan yang akan diuraikan di ayat-ayat selanjutnya. Ini menandai awal suatu pokok pikiran yang baru.

- Teks ini juga dimulai dengan frasa "Yesus mengatakan ..." Frasa seperti ini umumnya digunakan sebagai pendahuluan dari sebuah pokok pikiran dalam perikop-perikop lain (misalnya: Luk. 6:20; 8:22; 9:18; 9:22; 9:49; 12:22; 12:54; 13:6; 13:18; 14:12; 15:11; $16: 1 ; 17: 1 ; 18: 1 ; 18: 9 ; 18: 31 ; 19: 11 ; 20: 9 ;$ dan 20:40).

- Perikop sebelumnya (Luk. 17:20-37) memang masih memiliki keterkaitan yang kuat dengan perikop ini. Walaupun demikian, 17:20-37 berperan sebagai latar belakang (konteks) saja bagi 18:1-

16. Dengan menggunakan narasi pencobaan Yesus di padang gurun (Lukas 4:1-14a), David K. Bryan menunjukkan perlakukan pendekatan strukturalis terhadap teks tersebut dalam "The Center of Luke's Temptation Narrative," The Catholic Biblical Quarterly 82, no. 3 (July 2020): 407-23. 
8. Jadi, walaupun 17:20-37 (tentang parousia) dan 18:1-8 (sikap yang benar dalam menanti parousia) masih memiliki keterkaitan, dua perikop ini memiliki dua gagasan dengan penekanan yang berbeda.

- Perikop setelahnya (Luk. 18:9-14) tampaknya membahas topik yang sama dengan 18:1-8, yaitu doa, tetapi sebenarnya mereka adalah dua pembahasan yang berbeda walau masih ada keterkaitan. Lukas 18:9-14 menekankan sikap yang benar di hadapan Allah, sedangkan 18:1-8 menekankan sikap yang benar dalam penantian eskatologis.

- Selain itu, kata "Dan ..." serta pengungkapan tujuan perumpamaan di awal 18:9-14 menunjukkan awal dari suatu pokok pikiran yang baru.

C. Kesatuan Teks

- Kesatuan teks sebagai satu unit pikiran didukung dengan adanya konsep yang sama yang muncul berulang-ulang:

○ “Doa” (ay. 1) dan "siang malam berseru” (ay.7)

○ “Tidak jemu-jemu” (ay. 1), "selalu datang" (ay. 3), "terus saja” (ay.5), dan "iman" (ay. 8).

○ "Beberapa waktu lamanya" (ay. 4), dan "mengulur-ulur waktu" (ay.7).

- Adanya suatu inklusio antara ayat 1 dan ayat $8 \mathrm{~b}$, yaitu antara "penegasan untuk berdoa dengan tidak jemu-jemu dalam penantian eskatologis" dan "iman (dalam bentuk doa yang tidak jemu-jemu) dalam penantian eskatologis." 
- Adanya paralelisme (bukan alegorisme) dalam bentuk argumen a minori ad maius (dari hal yang lebih kecil menuju hal yang lebih besar). Argumen ini tampak dalam hubungan antara:

- Hakim yang lalim (ay. 2) yang dikontraskan dengan Allah (ay. 7)

○ Janda (ay. 3) yang dihubungkan dengan orang-orang pilihan Allah (ay.7)

○ Ketekunan janda (ay. 3) dengan ketekunan dan iman orang-orang pilihan (ay. 7-8)

- Adanya hubungan yang erat antara:

○ Tujuan perumpamaan (ay. 1)

○ Isi perumpamaan (ay. 2-5)

○ Makna perumpamaan (ay. 6-7) dan

○ Kesimpulan perumpamaan (ay. 8b)

- Pasal 18:9-14 mengisahkan topik baru, yaitu sikap yang benar di hadapan Allah, yang merupakan unit yang berbeda dengan 18:1-8.

Kesimpulan: Lukas 18:1-8 merupakan satu unit pikiran yang berbeda.

D. Pembagian Struktur Teks

Lukas 17:20-18:8 dapat dibagi menjadi dua bagian:

I. 17: 20-37 I. Kesulitan besar akan mendahului kedatangan Anak Manusia.

II.18:1-8 II. Sikap orang percaya dalam penantian eskatologis adalah dengan cara selalu berdoa dengan tidak jemujemu.

A. Ay. 1 Tujuan perumpamaan: supaya murid-murid menyatakan sikap iman melalui doa yang tidak jemu-jemu dalam penantian eskatologis.

B. Ay. 2-5 Isi perumpamaan: hakim yang lalim dan janda yang tekun. 
1. Ay. 2 Gambaran hakim yang lalim.

1.1. Ay. 2a la tidak takut akan Allah.

1.2. Ay. $2 \mathrm{~b}$ la tidak menghormati seorangpun.

2. Ay. 3 Gambaran janda yang tekun.

2.1. Ay. 3a la selalu datang kepada hakim itu.

2.2. Ay. $3 \mathrm{~b}$ la selalu memohon keadilan bagi perkaranya.

3. Ay. 4-5a Respon hakim itu terhadap ketekunan janda tersebut.

3.1. Ay. 4a la menolak untuk beberapa waktu lamanya.

3.2.Ay. 4b-5a la akhirnya membela perkara janda itu.

4. Ay. 5 Motivasi dan tujuan hakim itu membela perkara janda tersebut.

4.1. Ay. 5a Motif: karena janda itu menyusahkan dia.

4.2. Ay. $5 \mathrm{~b}$ Tujuan: supaya jangan janda itu terus datang dan menyerang dia.

C. Ay. 6-8a Makna Perumpamaan.

1. Ay. 7-8a Respon Allah atas seruan orang-orang pilihan-Nya.

1.1.Ay. 7a Allah akan membenarkan orang-orang pilihan-Nya.

1.2. Ay.7b Allah tidak mengulur-ulur waktu sebelum menolong mereka.

1.3. Ay. 8a Allah segera membenarkan mereka.

D.Ay. 8b Kesimpulan: Apakah Anak Manusia akan mendapati sikap iman (tercermin melalui doa yang tidak jemujemu) dalam diri murid-murid ketika la datang untuk kedua kalinya?

E. Struktur Injil Lukas ${ }^{17}$

1. Pembukaan

2. Yesus di Galilea

3. Perjalanan ke Yerusalem

3.1. Pemuridan

(9:51-10:42)

3.2. Allah Bapa

3.3. Pertanyaan Mengenai Kelakuan Yesus

17. J. B. Green, The New International Commentary on the New Testament: The Gospel of Luke (Grand Rapids: Eerdmans, 1997), 25-29; David A. de Silva, An Introduction to the New Testament Context, 311. 
3.4. Berjaga-jaga

3.5. Anggota Kerajaan Allah

3.6. Menanggapi Kedatangan Kerajaan Allah

(17:11-19:27)

3.6.1.Ucapan Syukur dari Seorang Kusta

3.6.2. Kesetiaan Menyambut Kedatangan Anak Manusia

3.6.2.1. Kapan Kerajaan Allah akan Datang?

3.6.2.2. Di mana Kerajaan Allah itu?

3.6.2.3. Kesetiaan Dalam Penantian Kerajaan Allah

3.6.3.Bagaimana Memasuki Kerajaan Allah

(18:1-8)

4. Yesus di Yerusalem dan sekitarnya

Berdasarkan analisis struktur, batasan, kesatuan, dan pembagian teks di atas, penafsir dapat menemukan "amanat teks" (makna) penulis, yaitu "Yesus ingin murid-murid-Nya selalu berdoa dengan tidak jemu-jemu untuk mendapatkan keadilan Allah selama masa penantian parousia." Dengan demikian, aspek paradigmatik (deep structure) tampak jelas setelah dilakukan penelitian terhadap aspek sintagmatik (surface structure). Melalui pemaparan di atas, sumbangsih strukturalisme terlihat dengan jelas bagi proses penafsiran Alkitab, khususnya dalam aspek analisis konteks sastra. Fokus yang begitu rinci dan ketat terhadap teks akan menolong penafsir menemukan makna dari teks tersebut.

Memperlakukan Teks Menurut Genre Teks Tersebut

Oleh karena strukturalisme berorientasi pada teks, maka keunikan dan segala sesuatu yang terlibat di dalam teks menjadi perhatian utama. Selain perhatian yang begitu rinci terhadap struktur teks, sumbangsih strukturalisme dalam dunia penafsiran Alkitab juga terlihat dalam hal memperlakukan teks seturut dengan genre teks tersebut. Berbeda dari pendekatan yang berpusat pada pengarang (author-centered), 
strukturalisme melihat teks bersifat otonom tanpa dipengaruhi oleh pribadi di belakang teks tersebut, yaitu sang pengarang. Hal ini akan tampak sangat jelas dalam genre puisi. Ambil contoh Mazmur 8:2-10. ${ }^{18}$

2. Ya TUHAN, Tuhan kami, betapa mulianya nama-Mudi seluruh bumi! Keagungan-Muyang mengatasi langit dinyanyikan.

3. Dari mulut bayi-bayi dan anak-anak yang menyusu telah Kauletakkan dasar kekuatan karena lawan-Mu, untuk membungkamkan musuh dan pendendam.

4. Jika aku melihat langit-Mu, buatan jari-Mu, bulan dan bintang-bintang yang Kautempatkan:

5. apakah manusia, sehingga Engkau mengingatnya? Apakah anak manusia, sehingga Engkau mengindahkannya? 6. Namun Engkau telah membuatnya hampir sama seperti Allah, dan telah memahkotainya dengan kemuliaan dan hormat.

7. Engkau membuat dia berkuasa atas buatan tangan-Mu; segala-galanya telah Kauletakkan di bawah kakinya:

8. kambing domba dan lembu sapi sekalian, juga binatang-binatang di padang;

9. burung-burung di udara dan ikan-ikan di laut, dan apa yang melintasi arus lautan.

10. Ya TUHAN, Tuhan kami, betapa mulianya nama-Mu di seluruh bumi!

Pendekatan author-centered umumnya akan mendekati teks ini secara diakronik, yaitu dengan mempelajari latar belakang penulis serta konteks sejarah dan budaya pada waktu teks ini ditulis. Penafsir authorcentered akan melihat teks ini dalam terjemahan-terjemahan yang lain untuk mendapatkan keaslian teks (dalam hal ini penafsir melakukan kritik teks). Berbeda dengan penafsir author-centered, strukturalisme melihat

18. Versi yang dipakai ialah TB-LAI. 
teks ini secara sinkronik, berdiri sendiri, dan otonom. Dengan melepaskan pengarang dari teks, strukturalisme melihat Mazmur 8:1-9 sebagai sebuah karya dengan mempertimbangkan unsur-unsur sastra di dalamnya. ${ }^{19}$ Unsur-unsur yang dimaksud meliputi banyak hal, seperti: ${ }^{20}$

a. repetisi atau pengulangan (ay. 2 dan 10)

Pemazmur mengawali rangkaian mazmur ini dengan frasa: "Ya TUHAN, Tuhan kami, betapa mulianya nama-Mu di seluruh bumi!" Bagian ini merupakan pengulangan yang menjadi penekanan dalam Mazmur. Hal ini disebut sebagai chorus seperti yang muncul dalam Mazmur 62. Dalam Mazmur 62, chorus muncul pada ayat 2 dan 6 . Pada Mazmur 8 ini, repetisi atau chorus muncul pada ayat 2 dan 10 . Selain untuk memberikan penekanan, repetisi juga berfungsi untuk menarik perhatian pembaca atau pendengar Mazmur tentang isi yang ingin disampaikan oleh pemazmur. ${ }^{21}$

b. komposisi inklusio (ay. 2 dan 10)

Karena letaknya di awal dan akhir bacaan, repetisi ini membentuk inklusio. Inklusio menjadi sebuah perangkat sastra (literary device) yang berguna untuk mengikat pokok pikiran atau pesan utama yang ingin

19. Jun Kim, “Psalm 8: An Ecological Reading,” 한국기독교신학논총101 (July 2016): 11-30; Dan T. Lioy, "From Dignity to Disgrace: A Comparative Analysis of Psalms 8 and 14," Conspectus 1 (March 2013): 207-241.

20. Osborne, The Hermeneutical, 228. Pembahasan mendalam juga disajikan oleh Klein, et al., Introduction, 65-71; Terence Erling Fretheim, "God, Creation, and the Pursuit of Hapiness," Canon \& Culture 6, no. 1 (2012): 5-38.

21. Fretheim, "God, Creation, and the Pursuit of Hapiness," 15. 
disampaikan oleh penulis. ${ }^{22}$ Dalam Mazmur ini, inklusio menggaungkan kemuliaan TUHAN yang terwujud melalui ciptaan alam semesta dan manusia. Inklusio juga menolong menjadi pagar pembatas agar pembaca atau pendengar tidak kehilangan sentral atau fokus terhadap isi utama Mazmur.

c. bentuk kiasme yang mengerucut di ayat 4 .

Perangkat sastra lain yang kerapkali muncul dalam puisi ialah kiasme. Kiasme ialah perangkat sastra yang menggambarkan cerminan sintaksis dari satu atau lebih pasang kalimat yang memuat pokok pikiran yang sama. Kiasme biasanya menunjukkan pokok pikiran pada tengah cerminan sintaksis. Pada Mazmur 8, struktur kiasme ditunjukkan demikian: ${ }^{23}$

A. Ascription of Praise (v.1a)

B. The Glory of the Great King (vv.1b-2)

C. God's Interest in Humankind (vv.3-4)

C'. Humankind's Derived Glory (v.5)

B'. Humankind's Glory as Ruler (vv.6-8)

A'. Concluding Ascription of Praise (v.9)

Selain untuk menunjukkan keindahan nuansa sastra yang ada dalam Mazmur ini, struktur kiasme juga dimaksudkan untuk memudahkan

22. O. Palmer Robertson, "The Alphabetic Acrostic in Book I of the Psalms: An Overlooked Element of Psalter Structure," Journal for the Study of the Old Testament 40, no. 2 (2015): 225-238, https://doi.org/10.1177\%2F0309089215621 218.

23. William A. Van Gemeren, The Expositor Bible Commentaries: Psalms (eds., Temper Longman III dan David E. Garland; Grand Rapids: Zondervan, 2008), 137. 
pembaca menemukan ide sentral padanan sintaksis yang hendak disampaikan oleh penulis. Dalam Mazmur 8, ide ini mewujud dalam komponen ayat 3-5, khususnya di ayat 4 yaitu Allah yang mulia memiliki minat (interest) kepada manusia yang fana.

d. Paralelisme klimaks di ayat 4.

Dengan sendirinya, kiasme pada bagian sebelumnya menolong pembaca untuk melihat klimaks yang ingin disampaikan pemazmur melalui paralelisme bertingkat pada gabungan ayat 3-5. Klimaks ini memunculkan kontras jika dihubungkan dengan repetisi dan inklusio pada pembahasan sebelumnya. Repetisi dan inklusio pada ayat 2 dan 10 mengusung tema sentral tentang keagungan Tuhan yang tercermin melalui alam semesta dan manusia. Kontras ini terlihat ketika kiasme menunjukkan bahwa minat utama dari Tuhan yang agung itu justru ditunjukkan kepada manusia yang fana pada ayat 3-5. Ini menjadi kontras yang menghasilkan klimaks bagi pembaca: sebuah kekaguman akan kebesaran Allah, bukan hanya dalam ciptaan-Nya, tetapi dalam cara-Nya memperlakukan manusia, ciptaan-Nya yang fana. ${ }^{24}$

Penggalian yang lebih dalam terhadap struktur teks, sebagaimana ditunjukkan di atas, menolong penafsir untuk melihat teks ini sebagai sebuah puisi, sesuai dengan genrenya. ${ }^{25}$ Dengan demikian, strukturalisme

24. Robertson, "The Alphabetic Acrostic in Book I of the Psalms: An Overlooked Element of Psalter Structure," 237.

25. Kory Eastvold, "The Image of God in Old Testament Theology," StoneCampbell Journal 21, no. 2 (Fall 2018): 239-51. Begitu juga halnya dengan bentuk narasi. Strukturalisme, dalam hal ini Kritik Narasi, akan mengamati unsur-unsur pembentuk narasi di dalam teks, seperti: implied author dan narrator, point of view, 
memberikan sumbangsih bagi dunia penafsiran Alkitab, khususnya dalam hal memperlakukan teks seturut dengan genre teks tersebut.

Selain sumbangsih, strukturalisme juga memiliki kelemahan terkait dunia penafsiran Alkitab. Kelemahan strukturalisme tampak dalam dua hal: pertama, pendekatan strukturalisme bersifat ahistorikal; kedua, strukturalisme mengabaikan pengarang dan sudut pandang teologinya untuk mendapatkan pemaknaan teks.

\section{Bersifat Ahistorikal}

Salah satu kelemahan strukturalisme adalah bahwa pendekatan ini mengabaikan aspek diakronik teks. Dalam hal ini, konteks budaya dan sejarah dari teks bukan merupakan minat dan fokus strukturalisme. Fokus yang berlebihan terhadap sejarah dan budaya tentunya akan menggeser pesan otentik teks yang sedang diteliti. Namun sikap yang sepenuhnya mengabaikan konteks sejarah dan budaya akan membuat teks tersebut tidak dipahami secara utuh. Sebagai contoh, dalam perumpamaan tentang hakim yang tidak benar tadi, Lukas memunculkan dua sosok dalam tulisannya: hakim dan janda. Protagonis dan antagonis ini sesungguhnya memainkan peranan penting dalam mengusung tema pengarang. Namun secara teologis, perumpamaan ini akan kehilangan cengkeraman maksimalnya jika analisis konteks sejarah dan budaya tidak dilakukan.

plot, characterization serta dialogue, dan setting (Osborne, The Hermeneutical, 20212). 
Dalam budaya Yahudi, hakim adalah orang dengan kuasa yang luar biasa. ${ }^{26}$ Hakim adalah wakil Allah untuk menyatakan keadilan dan kebenaran bagi mereka yang tertindas. Hakim adalah pemegang keputusan terakhir, tanpa juri atau naik banding. Praksis hakim harus selalu didasarkan pada hukum Musa sebagai dasar kebenaran. ${ }^{27}$ Dalam konteks Yudaisme, takut akan Allah merupakan syarat mutlak bagi seorang hakim (2Taw. 19:6-7). Sebaliknya, hakim dalam perumpamaan ini memiliki karakter yang bertolak belakang dari karakter yang seharusnya dimiliki oleh seorang hakim. Hakim dalam perumpamaan ini tidak takut akan Allah dan tidak menghormati seorangpun. Dengan menyatakan karakter hakim seperti ini, Tuhan Yesus ingin memperlihatkan betapa bobrok dan bejatnya hakim itu.

Berkaitan dengan tema eskatologis sebagai bingkai perumpamaan ini, maka Anak Manusia digambarkan akan datang kembali sebagai Hakim untuk menyatakan keadilan dan kebenaran Allah yang sejati bagi seluruh umat manusia (Luk. 18:8 band. Mat. 19:28). Dengan menggunakan sosok hakim yang lalim ini, Tuhan Yesus ingin memunculkan kontras yang sangat menyolok antara hakim duniawi dan Hakim llahi. ${ }^{28}$

Begitu juga halnya dengan janda. Di dalam budaya Yahudi yang patriarkhal, wanita (secara khusus janda) merupakan kelompok

26. Matteo Crimella, "God Is Not Like That Judge (Lk. 18:1-8)," Studia Biblica Slovaca 9, no. 1 (2017): 88-103.

27. Büchsel. "крıтn's" dalam Theological Dictionary of New Testament (eds. Gerhard K., and Gerhard F.; Grand Rapids: Eerdmans, 1975), 936-38; R. E. V. Harn, The Lectionary Commentary: Theological Exegesis for Sunday's Text (Grand Rapids: Eerdmans, 2001), 429.

28. Crimella, “God Is Not Like That Judge," 99-100. 
masyarakat yang tersubordinasi, baik dalam lingkup politik, religius, maupun sosial. ${ }^{29}$ Lebih buruk lagi, janda merupakan sosok yang amat mengenaskan. Dalam konteks masyarakat Yahudi pada waktu itu, mereka biasanya adalah orang-orang yang kekurangan dan tanpa pertolongan. ${ }^{30}$ Janda adalah orang-orang tanpa pertahanan dalam masyarakat Ibrani. Perjanjian Lama menunjukkan bahwa mereka seringkali ditekan (Mal. 3:5), diperas (Kel. 22:22-24), dan menjadi korban hukum serta pengadilan (Yes. 1:17, 23). ${ }^{31}$ Di sisi yang lain, janda seringkali digambarkan sebagai penerima kebaikan dan pertolongan Allah. Mazmur 68:5 menyatakan bahwa "Allah adalah Pelindung bagi para janda."

Berbanding terbalik dengan konteks budaya Yahudi pada waktu itu, Lukas dalam Injilnya memberikan penghargaan yang sangat positif bagi kaum wanita dan janda. ${ }^{32}$ Dalam perumpamaan ini, janda tersebut merupakan protagonis yang menerima tekanan masyarakat dan ketidakadilan sosial. Itu sebabnya ia berkata kepada hakim itu, "Belalah hakku terhadap lawanku." (18:3). Namun, sistem peradilan kuno adalah milik laki-laki. Fakta bahwa janda ini datang sendirian ke pengadilan

29. C. C. Kroeger, "Woman in Greco-Roman World and Judaism" dalam Dictionary of the New Testament Background (eds. C. A. Evans and S. E. Porter; Illinois: IVP, 2000), 1276-1280.

30. I. H. Marshall, New International Greek Testament Commentary: Commentary on Luke (Grand Rapids: Eerdmans, 1986), 672.

31. "The Care of Widows and Orphans in the Bible and the Ancient Near East" NIV Archaeological Study Bible (Grand Rapids: Zondervan, 2005), 285.

32. Injil Lukas adalah Injil yang memberikan perhatian yang paling besar bagi sosok wanita dan janda. (D. G. Reid, The IVP Dictionary of the New Testament [Illinois: IVP, 2004], 1101). Hal ini juga dipaparkan dalam de Silva, An Introduction to the New Testament Context, 332. 
menunjukkan bahwa ia tidak memiliki satu pun kerabat yang dapat membawa perkaranya ke pengadilan. la juga harus terus-menerus membawa perkaranya ke pengadilan. Hal ini menunjukkan kemiskinannya (ia tidak mampu menyogok hakim itu agar membuat perkaranya lebih cepat ditangani). Itu juga merupakan alasan mengapa hakim itu menolak mengurus perkaranya. ${ }^{33}$

Selain itu, janda ini juga digambarkan sebagai seorang wanita yang gigih dan tulus. Kegigihannya tampak jelas pada penggunaan kata "selalu" (ay. 3) dan "terus saja” (ay. 5). Frasa "beberapa waktu lamanya” dalam ayat 4a juga menyiratkan hal yang sama. Ketulusan janda ini dinyatakan melalui

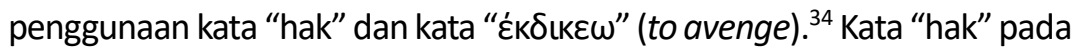
ayat 3 menunjukkan bahwa janda ini sebenarnya tidak menginginkan balas dendam, tetapi keadilan atas perkaranya. Besar kemungkinan, ini adalah perkara keuangan dimana lawannya menahan hak yang seharusnya adalah miliknya. ${ }^{35} \mathrm{Hal}$ ini juga ditegaskan oleh NIGTC bahwa

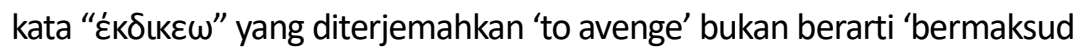
membalas dendam', melainkan "to procure justice for someone." ${ }^{\prime 36} \mathrm{Hal}$ ini membuktikan bahwa janda itu berada pada posisi orang yang benar. la datang kepada hakim itu supaya perkaranya dibela dan ia mendapatkan keadilan sebagaimana mestinya. Lebih jauh lagi, apa yang diinginkan oleh janda itu bukanlah supaya lawan perkaranya dihukum, tetapi apa yang

33. Green, The New International Commentary, 639-40.

34. John G. Nordling, "A Devotion on Luke 18:1-8," Concordia Theological Quarterly 79, no. 3-4 (July-October 2015): 347-49.

35. Stählin. "хń $\rho \alpha "$ dalam Theological Dictionary of New Testament (eds. Gerhard K., and Gerhard F.; Grand Rapids: Eerdmans, 1974), 444-52.

36. Marshall, New International Greek Testament Commentary, 672. 
seharusnya menjadi haknya diberikan kepadanya oleh lawannya. Kegigihan janda ini nantinya (ayat 7) akan dihubungkan dengan keteguhan iman orang-orang pilihan Allah yang nyata dalam doa yang tidak jemujemu (siang malam berseru kepada Allah) untuk mendapatkan keadilan Allah. ${ }^{37}$

Dengan mempertimbangkan latar belakang sejarah dan budaya, penafsir akan lebih melihat kekayaan dan kedalaman makna sebuah teks. Strukturalisme memang memberikan sumbangsih yang sangat baik dalam analisa struktur, tetapi dalam analisa latar belakang sejarah dan budaya, strukturalisme tidak memberikan sumbangsih sama sekali. Lebih jauh dapat dikatakan bahwa strukturalisme mereduksi teks, dalam hal ini mencopot teks, dari konteksnya ke dalam batas kode-kode dan struktur tanda bahasa. Strukturalisme menunjukkan kelemahan dalam hal ini karena akan membuat penafsir lalai melihat keterkaitan teks sebagai "texture" atau jalinan teks. Jalinan ini hanya dapat dipahami jika teks dilihat berdasarkan konteks. Walter C. Kaiser, seorang tokoh penting dalam dunia hermeneutika Alkitab, sependapat dengan hal ini. Kaiser mengingatkan bahwa, "To view the "texture" of biblical literature as the beginning and end of our interest would be to undermine what traditionally has been recognized as a foundational element of biblical religion, namely its essentially historical character."38 Inilah yang tidak dapat ditangkap oleh strukturalisme.

37. Kurt A. Lantz, "Will There Be Faith without Widows? (Luke 18:1-8)," Lutheran Theological Review 26 (2014): 89-92.

38. Walter C. Kaiser, Jr., dan Moisēs Silva, Introduction to Biblical Hermeneutics (Grand Rapids: Zondervan, 2007), 285. 
Mengabaikan Pengarang dan Sudut Pandang Teologinya

Karena pendekatannya yang menitikberatkan pada teks, strukturalisme mengabaikan eksistensi dan sudut pandang teologis pengarang teks. Kelemahan ini sangat berbahaya bagi dunia penafsiran Alkitab. Kaiser dan Silva menegaskan bahwa "biblical narrative ... should not be treated as neutral in character, free of interpretative theological 'bias'."'39 Eksistensi dan sudut pandang pengarang jelas sangat penting dalam proses eksegesis Alkitab. Memahami sudut pandang teologi pengarang akan menolong penafsir untuk mendekati teks dengan lebih utuh.

Kembali kepada contoh dalam Lukas 18:1-8. Letak yang tidak biasa dari tujuan perumpamaan (yaitu di awal perikop) mengindikasikan usaha Lukas untuk mengusung tema tertentu dalam tulisannya. Sekalipun dalam pembukaan tulisannya Lukas mengatakan bahwa ia "membukukan dengan teratur" (1:3), dari segi genre seperti Injil-Injil yang lain, Injil Lukas tetap lebih merupakan sebuah buku pengajaran (katekisasi) ketimbang buku sejarah (historiografi). Sebagai sebuah buku pengajaran, Injil Lukas memiliki persepsi tertentu dalam memandang pribadi dan karya Kristus. Salah satu penekanannya berkaitan dengan tema "the delay of the Second Coming. ${ }^{\prime 40}$ David A. de Silva menggambarkan hal ini sebagai berikut:

In Luke's account of Jesus' teaching, there is a pronounced emphasis on combating expectation of God's final intervention happening immediately. This would have been quiet appropriate in the context of Jesus' own ministry, since ancient people typically looked for a

39. de Silva, An Introduction to the New Testament Context, 332.

40. de Silva, An Introduction to the New Testament Context, 332. 
person identified as the Messiah to act at once to bring about God's purposes for the nation of Israel, leading the nation in a successful revolt against the Gentiles overlords and restoring political independence. $^{41}$

Berbeda dari penekanan Injil-Injil yang lain, Lukas memandang bahwa fokus dalam penantian Kerajaan Allah bukanlah pada cepat atau lambatnya Kerjaan itu datang, tetapi pada bagaimana orang-orang Kristen mengisi masa-masa penantian itu. Dalam hal ini yaitu dengan doa yang tidak jemu-jemu.

Pemaknaan seperti ini tidak mungkin didapatkan jika berhenti pada pendekatan strukturalisme saja. Strukturalisme, dengan mengabaikan eksistensi dan sudut pandang teologi pengarang, menyebabkan penafsir gagal melihat signifikansi sudut pandang teologi pengarang dan dampaknya terhadap pemaknaan teks secara utuh.

\section{Kesimpulan}

Pemaparan pada bagian strukturalisme sebagai sebuah perangkat hermeneutika modern menunjukkan bahwa strukturalisme telah memengaruhi banyak disiplin ilmu di dunia. Strukturalisme menitikberatkan proses penafsiran hanya pada unsur-unsur di dalam objek penelitian (teks) dan mengabaikan unsur-unsur di luarnya. Dalam author-text-reader, posisi strukturalisme adalah pada text. Strukturalisme memiliki aspek-aspek penting antara lain: struktur, langue dan parole, tanda atau sign yang dibentuk dari signifier dan signified, aspek

41. de Silva, An Introduction to the New Testament Context, 332. 
sintagmatik (surface structure) dan paradigmatik (deep structure), serta fokus pada sinkronik.

Sebagai sebuah pendekatan hermeneutika modern, strukturalisme memberikan sumbangsih yang sangat signifikan bagi dunia penafsiran Alkitab, terlepas dari kelemahan yang ada. Pembahasan pada bagian sumbangsih strukturalisme bagi dunia penafsiran alkitab menunjukkan bahwa strukturalisme memberikan sumbangsih, antara lain: pertama, strukturalisme mendorong para penafsir Alkitab untuk berorientasi pada teks; kedua, strukturalisme menolong penafsir Alkitab untuk memperlakukan teks berdasarkan genre teks tersebut. Kelemahan strukturalisme bagi dunia penafsiran Alkitab antara lain: pertama, pendekatan strukturalisme bersifat ahistorikal; dan kedua, strukturalisme mengabaikan pengarang dan sudut pandang teologinya untuk mendapatkan pemaknaan teks. Menimbang berbagai manfaat yang ditawarkan oleh strukturalisme sebagai sebuah perangkat linguistik, strukturalisme baik untuk terus digunakan. Saussure sendiri menyimpulkan bahwa "linguistic questions interest all who work with texts - historians, philologists, etc. Still more obvious is the importance of linguistics to general culture: in the lives of individuals and societies, speech is more important than anything else." ${ }^{\prime 2}$ Karenanya, para peneliti teologi layak untuk terus menggunakan dan mengkaji pendekatan ini sambil mawas diri dengan berbagai kelemahan yang ada!

42. Saussure, Course in General Linguistics, 7. 


\section{Daftar Pustaka}

\section{Buku}

"The Care of Widows and Orphans in the Bible and the Ancient Near East" NIV Archaeological Study Bible. Grand Rapids: Zondervan, 2005.

Büchsel. "крıтn's" dalam Theological Dictionary of New Testament. Eds. Gerhard K., and Gerhard F., 921-950. Vol. III. Grand Rapids: Eerdmans, 1975.

Corley, B. Biblical Hermeneutics. Nashville: Broadman \& Holman, 1996.

de Silva, David A. An Introduction to the New Testament Context, Methods, and Ministry Formation. Downers Grove: Intervarsity, 2004.

Fee, Gordon D., dan Douglas Stuart. How To Read the Bible for All Its Worth. Grand Rapids: Zondervan, 2003.

Gemeran, William A. Van. The Expositor Bible Commentaries: Psalms. Eds., Temper Longman III dan David E. Garland; Grand Rapids: Zondervan, 2008.

Green, J. B. The Gospel of Luke. The New International Commentary on the New Testament. Grand Rapids: Eerdmans, 1997.

Harn R. E. V. The Lectionary Commentary: Theological Exegesis for Sunday's Text. Grand Rapids: Eerdmans, 2001.

Klein, William W. et al. Introduction to Biblical Interpretation. Nashville: Thomas Nelson, 2004.

Kroeger, C. C. "Woman in Greco-Roman World and Judaism" dalam Dictionary of the New Testament Background. Eds. Evans C. A. and Porter S. E., 1276-1280. Illinois: IVP, 2000.

Marshall I. H. Commentary on Luke. New International Greek Testament Commentary. Grand Rapids: Eerdmans, 1986.

Osborne, Grant R. The Hermeneutical Spiral. Downers Grove: IVP, 2006.

Reid D. G. The IVP Dictionary of the New Testament. Illinois: IVP, 2004.

Sanders, Carol. "Introduction: Saussure today," dalam The Cambridge Companion to Saussure. Ed. Carol Sanders, 1-8. Cambridge: Cambridge University, 2004.

Saussure, Ferdinand de. Course in General Linguistics. Chicago: Open Court, 1986.

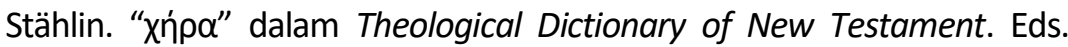
Gerhard K., and Gerhard F., 440-465. Vol. IX. Grand Rapids: Eerdmans, 1974. 
Thistleton, Anthony C. New Horizon in Hermeneutics. Grand Rapids: Zondervan, 1992.

Walter C. Kaiser, Jr., and Moisēs Silva, Introduction to Biblical Hermeneutics. Grand Rapids: Zondervan, 2007.

\section{Jurnal}

Amihay, Aryeh. "Biblical Myths and the Inversion Principle: A Neostructuralist Approach." Journal of Biblical Literature 137, no. 3 (2018): 555-79

Assiter, Allison. "Althusser and structuralism." The British Journal of Sociology 35 (1984): 272-96.

Bryan, David K. "The Center of Luke's Temptation Narrative." The Catholic Biblical Quarterly 82, no. 3 (July 2020): 407-23.

Crimella, Matteo. "God Is Not Like That Judge (Lk 18:1-8)." Studia Biblica Slovaca 9, no. 1 (2017): 88-103.

Eastvold, Kory. "The Image of God in Old Testament Theology." StoneCampbell Journal 21, no. 2 (Fall 2018): 239-51.

Fretheim, Terence Erling. "God, Creation, and the Pursuit of Hapiness." Canon \& Culture 6, no. 1 (2012): 5-38.

Hurtado, Larry W. "Fashions, Fallacies and Future Prospects in New Testament Studies," Journal of the Study of the New Testament 36, no. 4 (2014): 299-329.

Jensen, Jeppe Sinding. "Semiotics of Religion: Once Lost - and now Found." Religion 44, no.1 (January 2014): 130-35.

Kazen, Thomas. "Level of Explanation for Ideas of Impurity: Why Structuralist and Symbolic Models Often Fail while Evolutionary and Cognitive Models Succeed." Journal of Ancient Judaism 9 no. 1 (January 2018): 75-100.

Kim, Jun. “Psalm 8: An Ecological Reading." 한국기독교신학논총 101 (July 2016): 11-30.

Lantz, Kurt A. "Will There Be Faith without Widows? (Luke 18:1-8)." Lutheran Theological Review 26 (2014): 89-92.

Lioy, Dan T. "From Dignity to Disgrace: A Comparative Analysis of Psalms 8 and 14." Conspectus 1 (March 2013): 207-41.

Nordling, John G. "A Devotion on Luke 18:1-8." Concordia Theological Quarterly 79, no. 3-4 (July-October 2015): 347-49. 
FERDINAND DE SAUSSURE: Strukturalisme dan Sumbangsihnya 143

Robertson, O. Palmer. "The Alphabetic Acrostic in Book I of the Psalms: An Overlooked Element of Psalter Structure." Journal for the Study of the Old Testament 40, no. 2 (2015): 225-38, https://doi.org/10. $1177 \% 2 F 0309089215621218$. 